\title{
An investigation of the use of specific problem-solving strategies by mathematics teachers in lessons
}

\author{
Funda Aydın Güç ${ }^{1}$ and Dilay Daltaban ${ }^{2}$ \\ ${ }^{1}$ Giresun University, Faculty of Education, Turkey (ORCID: 0000-0002-3922-017X) \\ ${ }^{2}$ Ministry of National Education, Donand? Tillik Secondary School, Turkey (ORCID: 0000-0002-2639-1826)
}

\begin{abstract}
The aim of this study was to determine the strategies teachers offer to provide students with experience solving problems in the classroom. A total of 15 secondary school teachers serving in secondary schools were observed through 10 classes each, with no emphasis on the topics covered and grade levels taught. The researcher observing the classes performed a descriptive analysis of the problem-solving processes employed by the teachers through the lens of a series of known problem-solving strategies. The study revealed that the teachers employed a number of strategies as part of the q1problem-solving process. However, it was observed that the rate of application of strategies was rather low, even though specific strategies were nominally employed by the teachers. The study revealed that the strategy most frequently employed by the teachers during the problem-solving process was adopting a different point of view, while the strategy of making a drawing was also frequently applied. Moreover, the teachers employed the strategies of intelligent guessing and testing, working backwards, finding a pattern, solving a simpler analogous problem, and considering extreme cases, but with lesser frequency. On the other hand, the strategy of organizing data was not used by any of the teachers.
\end{abstract}

Keywords: Problem solving; Problem solving strategies; Classroom practice; Mathematics teachers' preferences

Article History: Submitted 31 October 2020; Revised 7 February 2021; Published online 17 February 2021

\section{Introduction}

Problem-solving is deemed the focus of mathematics education by the National Council of Teachers of Mathematics [NCTM] (1989), which contends that the problem-solving process should entail "construction of new mathematical information through the solving of problems, solving problems which arise in mathematics and in other contexts, adapting and applying a specific variety of applicable strategies with the purpose of solving problems, thinking in depth about mathematical problem-solving processes, and making adjustments to adapt" (p. 12). In this regard, questions such as "what is a problem?" and "what kind of problems should be employed in the classroom?" are among the issues debated in the field of mathematics education and teaching (Hembree, 1992). To this point, an awareness of the types of problems introduced in the classrooms is crucial for an analysis of students' proficiency with respect to various types of problems (Özmen, Taşkın, \& Güven, 2012).

Address of Corresponding Author

Funda Aydın Güç, PhD, Giresun University, Faculty of Education, Department of Mathematics Education, 28100, Giresun, Turkey.

$\triangle$ funda.guc@giresun.edu.tr

How to cite: Aydın-Güç, F. \& Daltaban, D. (2021). An investigation of the use of specific problem-solving strategies by mathematics teachers in lessons. Journal of Pedagogical Research, 5(1), 126-140. http:/ / dx.doi.org/10.33902/JPR.2021067307 
Research in this area has shown that teachers frequently employ particular types of problems in mathematics lessons while avoiding others. For instance, according to a number of studies, mathematics teachers have exhibited a marked preference for the types of problems that are presented in the textbooks (Foong \& Koay, 1997; Özmen et al., 2012). In this respect, Ho \& Hedberg (2005) note that teachers tend to opt more frequently for verbal and standard problems, although providing relevant training and support led to increased use of non-standard problems. Özmen et al. (2012) similarly reported that teachers make more frequent use of problems that are routine and brief in terms of their quantitative data content; that are loosely aligned with the curriculum; that lack a connection to daily life and do not contain unrelated data; or that do not lack required data. Furthermore, Ishida (2002) and Özmen et al. (2012) point out that teachers employ problems that can be solved using a variety of strategies, while Csíkos \& Szitányi (2020) revealed that teachers generally agree that problem-solving strategies should be taught explicitly. In this regard, Ling and Maat (2020) investigated the strategies used by teachers and to what degree they applied them, using a Likert-type scale to present the names of strategies to participants and asking them to indicate the degree to which they used them. The results indicated that most of the teachers reported frequent use of problem-solving strategies. Moreover, no significant difference was found between the degrees of strategy use among novice and experienced teachers. However, these results relied on the self-reporting of the teachers, rather than on direct observation of their behaviors. In an additional study by Bruun (2013), teachers were asked to report which strategies they used most frequently to develop their students' problem-solving skills. Through interviews, it was revealed that none of the teachers used all of the problem-solving strategies proposed by the National Mathematics Teachers Council, relying primarily on the strategy of making a drawing.

Other researchers (e.g., Foong \& Koay, 1997; Ho \& Hedberg, 2005; Ishida, 2002; Ling \& Maat, 2020; Özmen et al., 2012) have provided insights into the types of problems applied in classrooms and make it clear that mathematics teachers utilize problems requiring various strategies in their lessons. In some cases (e.g., Bruun 2013; Csíkos \& Szitányi, 2020; Ling \& Maat, 2020), studies have examined teachers' ideas about the use of strategy in lessons and their views on their experiences, but these do not provide information about their actual classroom practice. Overall, the problemsolving strategies employed by the teachers, as well as whether they employ multiple strategies for the solution of individual problems, have not been studied comprehensively; yet the literature is virtually unanimous in noting the importance of the experiences provided to students with respect to different problem-solving strategies (Baki, 2015; Ling \& Maat, 2020; Olkun \& Toluk, 2003; Silver, Ghousseini, Gosen, Charalambous, \& Strawhun, 2005).

\subsection{Problem-Solving Strategies and their Significance}

There are a number of distinct categorizations regarding problem-solving strategies, which are crucial to the problem-solving process (Altun, Memnun, \& Yazgan, 2007; Ministry of National Education [MoNE], 2018; Posamentier \& Krulik, 1998). These categorizations, however, basically focus on the same set of strategies, which have been classified by Posamentier and Krulik (1998) as working backwards, finding a pattern, adopting a different point of view, solving a simpler analogous problem, organizing data, guessing and testing, making a drawing, considering extreme cases and accounting for all possibilities. The definitions of these classifications are described in Table 1.

The literature emphasizes that the presentation of various means of finding a solution to a problem increases both the motivation levels and the participation of students (Silver et al., 2005). Moreover, it has a positive effect on the experience of competence (Schukajlow \& Krug, 2014) and promotes the connectedness of knowledge (Levav-Waynberg \& Leikin, 2012). It has also been found that thinking about and discussing more than one solution can improve students' learning (Rittle-Johnson \& Star, 2007). In this sense, Rittle-Johnson and Star (2009) asserted that comparing different solutions for the same problem brought about greater gains in procedural knowledge and flexibility in students than reflecting separately on individual solutions. Similarly, Achmetli, Schukajlow, and Rakoczy (2019) demonstrated that students who had the experience of creating 
Table 1

Problem-solving strategies (Posamentier \& Krulik, 1998)

\begin{tabular}{ll}
\hline Strategy & Definition \\
\hline Working Backwards & $\begin{array}{l}\text { Starting with the result and moving towards the initial information step } \\
\text { by step to solve the problem. } \\
\text { The solutions to certain problems present a sequence. This strategy } \\
\text { focuses on finding the rule on the basis of which the terms of that } \\
\text { sequence are developed. }\end{array}$ \\
Adopting a Different & $\begin{array}{l}\text { Applying a different perspective to the problem by solving it through } \\
\text { means other than the obvious. } \\
\text { Point of View }\end{array}$ \\
Solving a Simpler & $\begin{array}{l}\text { Sometimes, the scale of the quantitative data provided in a problem can } \\
\text { make the solution more difficult. Briefly put, this strategy entails using }\end{array}$ \\
Analogous Problem & $\begin{array}{l}\text { smaller numbers instead of comparable bigger ones to do away with } \\
\text { complexity. }\end{array}$ \\
Organizing Data & $\begin{array}{l}\text { Using certain forms of organizing data to come up with systematic } \\
\text { solutions. } \\
\text { Trial and error. Making approximations of the data provided in the } \\
\text { problem. } \\
\text { Coming up with visual representations of the connections depicting the }\end{array}$ \\
Guessing and Testing & $\begin{array}{l}\text { relationship between the data in a problem. } \\
\text { Using extreme cases for one of the variables while keeping the other } \\
\text { fixed. }\end{array}$ \\
Consing a Drawing & $\begin{array}{l}\text { Coming up with a solution in consideration of all cases that may arise } \\
\text { with respect to the solution required with respect to the problem. }\end{array}$ \\
Cases &
\end{tabular}

more than one solution for real-world problems developed greater procedural and conceptual knowledge in solving problems than those who did not. These benefits support Wheatley's (1984) contention that teachers' use of strategies for solving problems encourages students to employ various strategies and work towards self-improvement, as well as contributing to the development of the teachers themselves.

A number of studies have shown that specific strategies such as working backwards, simplifying problems, making a systematic list, looking for a pattern, and making drawings were influential in terms of increasing students' problem-solving capabilities (Altun et al., 2007). Yazgan and Bintaş (2005), for instance, found that primary school students were able to develop strategies despite a lack of previous training regarding problem-solving strategies, and that training in problem-solving strategies boosted their success in solving problems. Likewise, Taşpınar and Bulut (2012), Ramnarain (2014) and Barham (2020) all found that the use of strategies can be taught, and as such, teachers should choose problems designed to enable the development of students' skills in the use of various strategies. This expectation from the teacher is included among the mathematics teacher competences specified by the MoNE (2017); namely, mathematics teachers should "be able to use the applicable strategy to solve a problem and to apply different strategies to solve mathematical problems." In this respect, the NTCM (2000) refers to the teacher's role in problem-solving environments as choosing appropriate problems; overseeing the use of such problems in line with the objectives; and evaluating students' comprehension and utilization of the strategies, thus helping them to become good problem solvers. With these issues in mind, given that problem-solving is among the prominent components of most mathematics curricula and that problem-solving strategies are crucial to the process of solving problems, incorporating various experiences in terms of problem-solving strategies in the classroom is an inherently important part of mathematics education. Thus, the MoNE (2017) tasks mathematics teachers with training students with these skills. 
In developing the use of strategies among students, a number of studies mention the positive impact of using unordinary problems (Follmer, 2000). While Ho and Hedberg (2005) contend that teachers more often use verbal and standard problems in mathematics lessons, Ishada (2002) found that problems that can be solved through a multitude of strategies are also used by mathematics teachers. However, these studies do not offer detailed information on whether or not different types of problem-solving strategies are employed by teachers during the problem-solving process.

Therefore, it is important to develop awareness of this issue in terms of whether education programs are serving to provide individuals with the ability to apply problem-solving strategies in mathematics lessons, as well as to guide the training of teachers in this regard. As such, a review of the actual state of affairs regarding teachers' use of problem-solving strategies in mathematics lessons is crucial in ensuring that the objectives of mathematics education are being met. If the aim of education is to develop problem-solving skills, the benefit of experiencing strategies cannot be ignored. In this sense, the more options students have for finding a solution, the greater the learning gains they achieve. Moreover, solving problems via different strategies allows students to validate similar questions. Therefore, regardless of the teacher's pedagogical purpose in problemsolving, if the anticipated learning gain is problem-solving, it is expected that the strategies will be utilized.

\subsection{Purpose of the Study}

It is widely accepted that problem-solving is an integral part of mathematics learning, and that problem-solving strategies are important elements of the process of problem-solving (NCTM, 1989). As such, the use of problem-solving strategies in the classroom, as well as exposure to various types of strategies, is among the priorities of mathematics education (NCTM, 2000). However, on a practical level, it is not always clear that teachers make adequate use of strategies in their teaching. For instance, students may solve problems using differing strategies in their group or individual work. However, if their teachers do not open this up for discussion in the classroom, other students in the class cannot benefit from the ideas of their peers. In this sense, the teacher is responsible for managing the general experience of the whole class, and thus, it is important to understand the experiences that teachers provide in their lessons. With this in mind, the current study aimed to investigate how mathematics teachers employ various problem-solving strategies in their lessons by addressing the following research question: "What kinds of problem-solving strategies do mathematics teachers use in their lessons?" It should be noted that, while students are also active in the process, the focus in this case is on the teachers; therefore, the phrase "problem-solving strategies used by teachers" is used throughout this manuscript.

\section{Method}

\subsection{Research Design}

Detailed information on whether teachers employ different problem-solving strategies as part of their lessons, as well as which strategies are more prominent, can be gathered through extensive observation. This approach is believed to provide insight into an existing situation. Studies of this nature are referred to as case studies, as they focus on a special case, enabling the researcher to describe even the finest details of a matter with reference to causality and the mutual relationships between variables (Çepni, 2009). Because the current study constituted an in-depth examination of the participants during their practice, it can be considered as a case study.

\subsection{Participants}

The participants in this study, which took place in the fall semester of the 2016-2017 academic year, consisted of ten middle school mathematics teachers from four different schools. Because classroom practices vary according to teachers' levels of experience, all of the middle school mathematics teachers serving in the central district of Giresun province in Turkey were first grouped with reference to their years of service. Five teachers from each group were included on a 
voluntary basis in order to ensure the diversity of the sample. Namely, five teachers who had 0-8 years of experience, five with 9-14 years of experience, and five with 15 or more years of experience were included in the study, in line with Yıldırım and Şimşek's (2008) assertion that maximum diversity sampling is the creation of a sample from different situations related to the problem. In this study, the teachers' years of experience were taken as the basis for the maximum source of diversity. Because it is unknown whether level of experience affects teachers' approaches to solutions, it was believed that providing for diversity was important in eliminating potential bias in the study findings.

The participants were coded as T1, T2, T3, and so on, according to the order of observation, without reference to the school and years of experience involved. The demographics of the participants are presented in Table 2.

Table 2

\begin{tabular}{cccccc}
\multicolumn{2}{c}{ Demographic characteristics of the participants } \\
\hline Teacher & Experience & Grades Taught & Teacher & Experience & Grades Taught \\
\hline T1 & 9 years & 8th grade & T9 & 15 years & 6th and 7th grades \\
T2 & 10 years & 5th grade & T10 & 8 years & 5th grade \\
T3 & 16 years & 5th and 6th grades & T11 & 14 years & 8th grade \\
T4 & +15 years & 5th and 8th grades & T12 & 10 years & 7th and 8th grades \\
T5 & 7 years & 5th and 6th grades & T13 & +15 years & 5th and 6th grades \\
T6 & 13 years & 5th and 8th grades & T14 & +15 years & 6th and 7th grades \\
T7 & 4 years & 5th and 6th grades & T15 & 6 years & 5th and 7th grades \\
T8 & 8 years & 5th and 6th grades & & & \\
\hline
\end{tabular}

\subsection{Data Collection}

The mathematics lessons taught by the teachers were observed in order to identify the types of problem-solving strategies they used. The information obtained from these observations constituted the data for the study. The lessons to be observed were selected on the basis of a match between the timing of the lessons for each teacher and the time frames during which the researchers were available. A total of 10 lessons were observed for each teacher. The lessons were selected without consideration for differences in terms of the topics and the grades taught. The justification for disregarding these aspects lies in the existence of problems which enable the use of different strategies at each grade level and within each topic. During the process, the observing researcher took detailed notes of all questions the teachers handled as problems during the lessons, as well as their solution approaches for these questions. The lessons were also video recorded to prevent data loss. Following the observations, the notes were compared to the video recordings, and any oversights were addressed.

Afterward, the teachers' emphasis on problem-solving in the lessons was analyzed independently of the method applied for teaching. In other words, the problem-solving processes executed by the teachers were investigated based on the strategies they employed without specific reference to the approaches implemented, such as application of the solution on the blackboard following the introduction of the problem, requiring the students to come up with solutions, or enabling group inquiries into the problems and allowing a discussion of different solutions for a given problem. Such an attitude requires an analysis of the solution strategies exhibited in the processes, such as the teacher solving the problems on the blackboard or through group work, along with the strategies discussed in the classroom upon asking students to present potential approaches to the solution.

In this study, it was held that the crucial element in every learning environment was the experiences the students had with respect to the strategies. The prevailing state of affairs was depicted in line with the goals of the study, without any intervention in the educational approaches put forth by the teachers. Each lesson was observed by a single researcher, which allowed the teacher and students to become familiar with the researcher's presence. Carrying out 
the observations over an extended time frame without associating them with specific topics helped with presenting an overall picture. Following the observations, a process was carried out with the relevant participants to confirm unclear cases regarding problem-solving procedures.

\subsection{Data Analysis}

In research, the analysis of data according to previously determined themes is defined as descriptive analysis (Yıldırım \& Şimşek, 2008). In this study, the researcher observed the lessons and then analyzed the problem-solving processes employed by the teachers through the lens of the problem-solving strategies defined by Posamentier and Krulik (1998) in accordance with the practice of descriptive analysis. An example problem and its possible solutions are given below. The analysis process is exemplified through an explanation of the strategies used in the solutions.

Problem: 100 people will shake hands in pairs. How many handshakes are completed if everyone shakes hands one time with all of the others?

Solution approaches:

First approach:

It is known that there must be two people to shake hands. The individual considers how many ways two people from the group can be selected and reasons that this number should equal the number of handshakes. The individual also knows that choosing two people from a group is calculated by combination. In the light of this information, the solution is as follows:

$$
\begin{gathered}
\text { Number of pairs that can be created }=\text { Number of handshakes }=\left(\begin{array}{l}
n \\
2
\end{array}\right)=\frac{n(n-1)}{2} \\
=\frac{100 \cdot 99}{2}=4950
\end{gathered}
$$

Here, the individual directly follows a familiar procedure. If an individual directly uses his or her prior knowledge, such as models, equalities, and order of operations, in the solution of a problem, this constitutes a routine approach. In this case, the combination approach is a familiar technique that is often used in mathematics books. Therefore, this solution approach is considered as a routine solution, not as a strategy.

Second approach:

An individual can observe the number of handshakes that will take place starting from a minimum number of people. In this case, the resulting data will be as follows.

\begin{tabular}{llllllllll}
\hline $\begin{array}{l}\text { Number of people in } \\
\text { the group }\end{array}$ & 2 & 3 & 4 & 5 & 6 & 7 & 8 & $\ldots$ \\
\hline Number of handshakes & 1 & 3 & 6 & 10 & 15 & 21 & 28 & $\ldots$ \\
\hline
\end{tabular}

One can examine the relationship between the number of people and the number of handshakes from the data set, revealing the following, where $\mathrm{n}$ is the number of people.

$$
\text { Number of handshakes }=\frac{n(n-1)}{2}=\frac{100 \cdot 99}{2}=4950
$$

The problem can be answered by applying this relationship. This solution is evaluated as the strategy of finding a pattern.

Third approach:

In this problem, answers are requested for $\mathrm{n}$ people. The person who will solve the problem can first examine a group of 5 people to generate an idea for the solution of the problem and can formulate the problem as " $\mathrm{n}$ people will shake hands in pairs. How many handshakes are completed if everyone shakes hands one time with all of the others?" The individual works to solve this problem by assigning dots to represent 5 people and rays to indicate each person's handshake with the others. The resulting figure is as follows. 


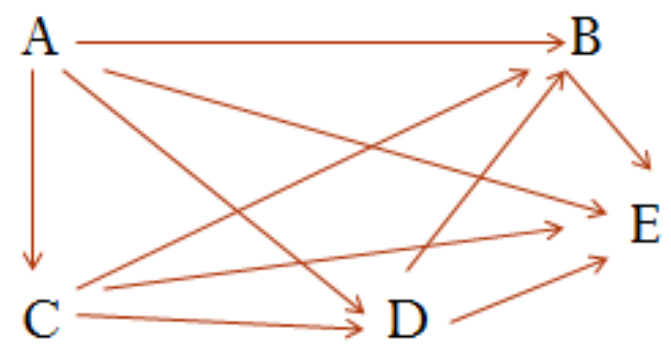

It can be can see that a pentagon is formed here. The individual notices that the handshake representations point to the sides and diagonals of the pentagon. Therefore, a model can be presented for the number of handshakes, where $\mathrm{n}$ is the number of people.

$$
\text { Number of handshakes }=\text { Number of diagonal }+ \text { Number of sides }
$$

$$
=\frac{n(n-3)}{2}+n=\frac{5 \cdot 2}{2}+5=10
$$

The individual can then check the accuracy of the result with the figure. After editing the expression a little more, it is brought to the form below:

$$
\begin{aligned}
& \text { Number of handshakes }=\frac{n(n-3)}{2}+n=\frac{n(n-3)+2 n}{2}=\frac{n(n-3+2)}{2}=\frac{n(n-1)}{2} \\
& =\frac{100 \cdot 99}{2}=4950
\end{aligned}
$$

In this case, the individual first reduced the problem to 5 people, rather than 100 , using smaller numbers instead of comparable larger ones to do away with complexity. Using five people enabled the creation of the model necessary for the solution of the main problem. This approach is considered as the strategy of solving a simpler analogous problem. The individual in this scenario also accounted for all possibilities, and according to those possibilities, made a drawing to reveal this relationship. This drawing provided a means to reveal the solution, rather than to understand the problem. As such, it can be said that the strategies of accounting for all possibilities and making a drawing strategy were put to work here. Therefore, this solution approach included three strategies.

If a teacher used two or three problem-solving strategies to solve a single problem, as in the example, all of the strategies were considered, and the teacher was coded as using both or all three strategies for the problem. All of the analyses of the data were carried out through this approach. In this sense, all strategies were considered, but only those strategies that appeared in the lessons were marked. If a different strategy had been observed in the analysis process, that solution strategy would also have been included in the classification, yet no such observation was made.

In order to ensure the reliability of the data analysis, the individual teachers' problem-solving processes in all lessons were analyzed by two separate researchers. Their analyses were compared, and the reliability percentage was calculated using the formula described in Miles and Huberman (1994):

$$
\text { Reliability }=\frac{\text { Number of agreements }}{\text { Number of agreements }+ \text { Disagreements }}
$$

The reliability percentage in this case was 0.87 . For the problems for which no agreement was reached between the two researchers about the strategy employed, the researchers discussed the issues and tried to arrive at an agreement. The problems for which no agreement could be reached were submitted to a third expert who is experienced in mathematics education and problemsolving strategies. The expert's analysis served as the guideline for each researcher to assess the solutions observed in the lessons and to identify the strategies employed. Once the analyses by all three researchers were completed, the researchers met and discussed the solution processes for which a common view was lacking. The discussions culminated in shared decisions on the solution of each problem. 
This procedure can be exemplified by considering the third solution of the problem given in the data analysis section. For this solution, one researcher thought that in the solution made for 5 people, the strategy of accounting for all possibilities was employed, while another felt that this strategy was not at the core of the solution. Both researchers expressed their opinions, but they could not agree on this issue. Thus, they consulted with the third expert, who questioned whether it was important at what stage the problem-solving strategy emerged. As a result, it was agreed that even if all possible situations were not considered for the solution of the main problem, putting it to work in solving a simpler analogous problem meant that the strategy was used.

\section{Results}

The findings regarding the teachers' use of strategies for problem-solving are crucial in terms of understanding how many of the problem-solving processes involved problem-solving strategies. The observations of the lessons taught by the teachers are presented in Table 3 with respect to the focus on problem-solving processes in the lessons and the frequency of using the problem-solving strategies.

Table 3

The teachers' focus on problem-solving and problem solving strategies in their lessons

\begin{tabular}{|c|c|c|c|c|c|c|c|}
\hline Teacher & $\begin{array}{l}\text { Number } \\
\text { of } \\
\text { Problems } \\
\text { Solved }\end{array}$ & $\begin{array}{l}\text { Number of } \\
\text { Strategies } \\
\text { Employed }\end{array}$ & $\begin{array}{l}\text { The ratio of the } \\
\text { total of } \\
\text { strategies to the } \\
\text { number of } \\
\text { problems }\end{array}$ & Teacher & $\begin{array}{l}\text { Number of } \\
\text { Problems } \\
\text { Solved }\end{array}$ & $\begin{array}{l}\text { Number of } \\
\text { Strategies } \\
\text { Employed }\end{array}$ & $\begin{array}{l}\text { The ratio of the } \\
\text { total of strategies } \\
\text { to the number of } \\
\text { problems }\end{array}$ \\
\hline $\mathrm{T} 1$ & 38 & 4 & 0.10 & T9 & 46 & 7 & 0.15 \\
\hline $\mathrm{T} 2$ & 63 & 3 & 0.04 & T10 & 15 & 17 & 1.13 \\
\hline T3 & 52 & 8 & 0.15 & T11 & 44 & 3 & 0.06 \\
\hline $\mathrm{T} 4$ & 44 & 8 & 0.18 & T12 & 72 & 1 & 0.01 \\
\hline T5 & 57 & 23 & 0.40 & T13 & 67 & 6 & 0.09 \\
\hline T6 & 61 & 3 & 0.04 & T14 & 38 & 1 & 0.03 \\
\hline $\mathrm{T} 7$ & 36 & 15 & 0.41 & T15 & 41 & 10 & 0.24 \\
\hline $\mathrm{T} 8$ & 38 & 1 & 0.03 & Total & 712 & 110 & 0.15 \\
\hline
\end{tabular}

The number of problems that the teachers solved in their lessons during the observations is referenced as the number of problems solved, and the number of problem-solving strategies employed in solving those problems is noted as the number of strategies employed. Moreover, the number of strategies per problem is termed the ratio of the total of strategies to the number of problems. A review of Table 3 reveals that the teachers in the study group solved a total of 712 problems in their lessons; with the teacher using the lowest number of problems solving a total of 15, while the one who employed the problems most frequently solved 72 . The range is clearly wide, but this did not pose a problem in terms of understanding the teachers' use of strategies, as every teacher who took part in the study employed problem-solving processes sufficiently to reveal how often they employed problem-solving strategies. In this regard, Table 3 reveals that the teachers used problem-solving strategies a total of 110 times during the observations. Given the total number of problems solved by the teachers during the lessons, this figure leads to an average of 0.15 in terms of the employment of problem-solving strategies in the problem-solving processes. A further glance at the individual teachers' utilization of problem-solving strategies reveals that 11 teachers used strategies at an average of less than 0.02, while four exceeded the 0.20 average. T10 was observed to employ the problem-solving strategies at the highest average (1.13), exceeding the average of 1 per problem by employing more than one problem-solving strategy for certain problems. 


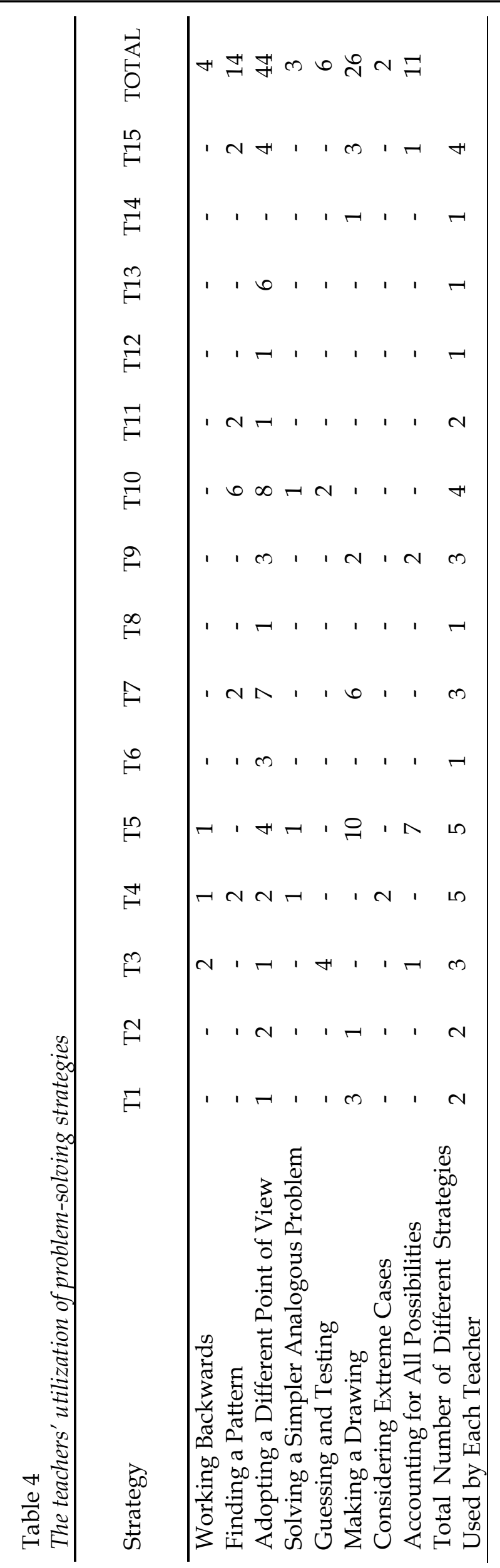


Table 4 reveals that the strategy most frequently employed by the teachers during the problemsolving processes was adopting a different point of view; it can also be seen that the strategy of making a drawing was frequently preferred. The teachers were also observed to employ the strategies of intelligent guessing and testing, working backwards, finding a pattern, solving a simpler analogous problem, and considering extreme cases, albeit less frequently. Furthermore, when the number of different strategies used by the teachers was examined, it was noted that a maximum of five different strategies was used (by two teachers). Overall, the teachers, who diversified the strategies in their lessons either focused on specific strategies (for example, although T10 used four different strategies, two different strategies were most often employed) or used strategies in only a small number of problems (for example, although T4 used five different strategies, the experiences that students were provided with respect to these strategies were limited to one or two problems). On the whole, it can be seen that most of the teachers (approximately 73\%) used a maximum of three strategies, with a considerable percentage (five teachers, approximately $33 \%$ ) using only one.

As an example, T5 had a total of 57 problem-solving instances in her observed lessons, 23 of which entailed the use of problem-solving strategies. In the problem " $7 / 13$ of the students in a class are girls. As the total number of girls in the class is 21, what is the total number of students in the class?" To provide a solution, T5 employed the strategy of making a drawing, as presented in Figure 1.

Figure 1

T5's approach to the solution using the strategy of making a drawing to solve the problem

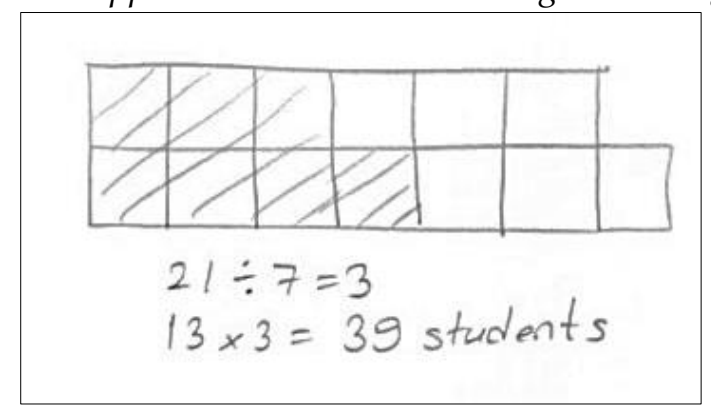

As the figure indicates, in solving this problem, $\mathrm{T} 5$ drew boxes to represent $7 / 13$. A 13-unit model was created, and 7 units were shaded; then the number of students per unit was calculated. The drawing that $\mathrm{T} 5$ made here allows students to identify the relationship between the whole and the pieces, providing them with a means to solve the problem. In this regard, it can be said that T5 used the strategy of making a drawing.

Another problem that could have been solved by making a drawing read, "Barıs used 2/7 of the cash he has to buy eight chocolates, each of which cost 0.5 liras. What was the amount of cash Barıs initially had? However, T5 solved this problem in a routine manner. The solution actually used by T5, along with the possible strategy of making a drawing that could have been used, are presented in Figure 2.

Figure 2

T5's routine approach to problem solution (1st solution) and the possible making a drawing strategy solution (2nd solution)

$$
\begin{aligned}
& 0,5 \times 8=4 T L \\
& 4 \div 2=2 T L \\
& 2 \times 7=14 \mathrm{TL}
\end{aligned}
$$

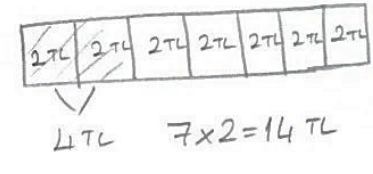

An examination of T5's solution approach for a problem similar to the previous problem reveals that this teacher used the usual sequential operations. The solution approach for such problems is 
usually to "divide by the denominator, multiply the numerator." This solution can often be encountered in books; hence, this is considered a routine solution. However, the problem may also be solved with the strategy of making a drawing, as with the previous problem. The second solution illustrated in Figure 2 can be examined to get an idea of how this approach might look in the classroom; however, the teacher only dealt with the routine solution of the problem.

In essence, while T5 applied the strategy of making a drawing in the first problem, a routine method was utilized in another problem where that strategy would have been appropriate. Failing to provide a solution through the strategy of making a drawing strategy served to deny the students that experience.

In another instance, T1 employed problem-solving strategies in just four out of the 38 problemsolving processes she carried out during the observed lessons. The two related problems and associated solutions are presented in Figures 3 and 4.

Figure 3

T1's approach to the problem employing both the routine approach and the strategy of adopting a different point of view

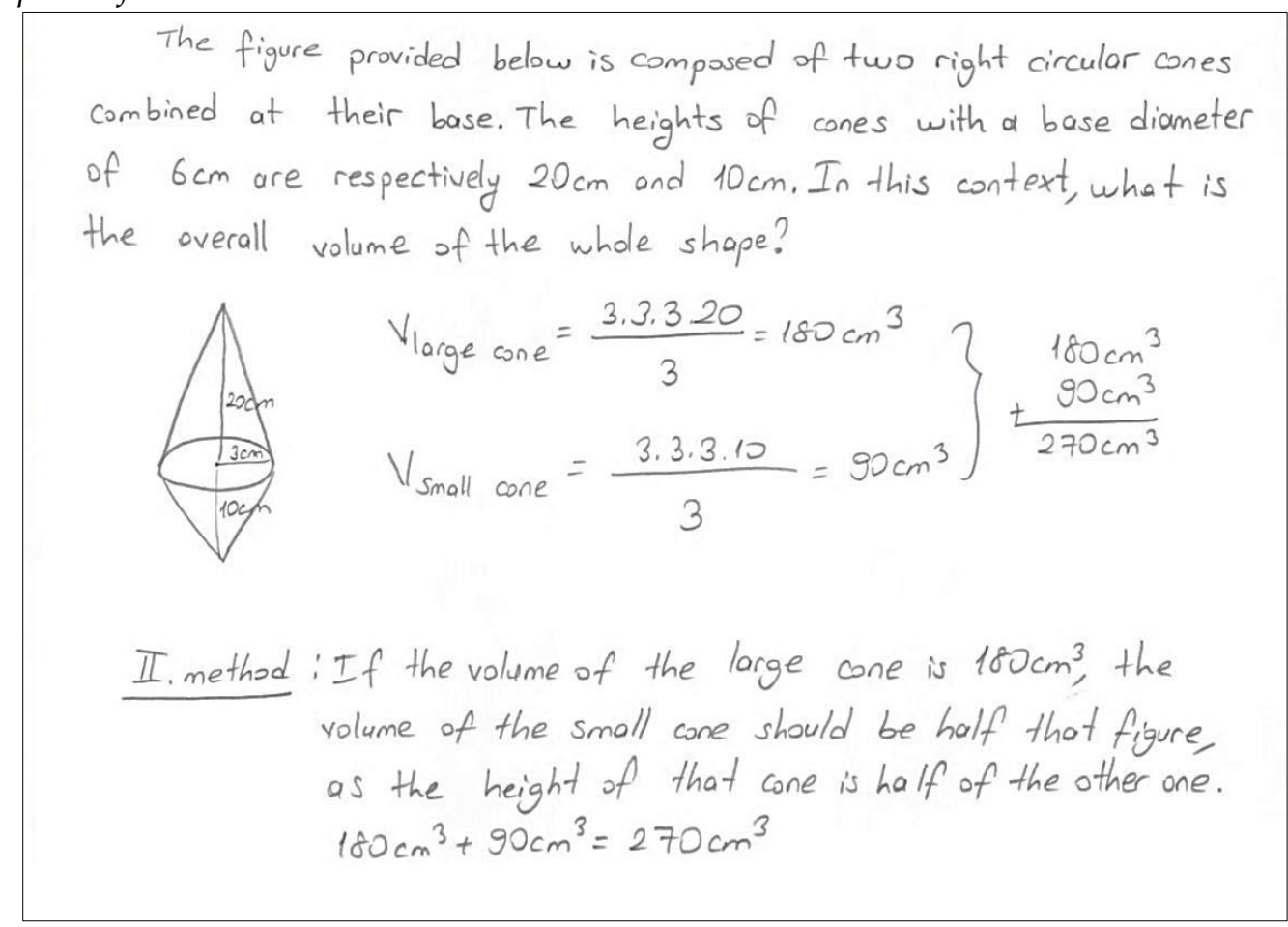

As seen in Figure 3, T1 addressed the problem with two different solutions. In the first solution, the problem was solved with the known volume calculation formulas. As such, this solution was classified as routine. On the other hand, in the second method, T1 first calculated the volume of the large cone, focusing on the relationship between heights rather than calculating the volume of the small cone and determining the volume of the small cone by identifying the ratio between heights. By focusing on heights, rather than volume, T1 applied the strategy of adopting a different point of view.

As with the problem given in Figure 3, T1 applied a similar solution to the problem presented in Figure 4. As can be seen, T1 solved the problem by using the volume calculation formulas, constituting a routine solution, as opposed to developing a different perspective by focusing on heights (as in Figure 3). A review of the problems and solutions presented in Figures 3 and 4 reveals that T1 referred to the solution through the strategy of adopting a different point of view for only one of two similar problems, using only a routine solution for the other. 
Figure 4

T1's routine solution for a problem which could as well be solved with the strategy of adopting a different point of view

The right rectongular prism with base edges measuring
$5 \mathrm{~cm}, 12 \mathrm{~cm}$, and $13 \mathrm{~cm}$, and a height of $20 \mathrm{~cm}$ was
filled with some water. If the height of the
water is $11 \mathrm{~cm}$, how much water is needed to fill
the rest of the prism (in $\left.\mathrm{cm}^{3}\right)$ ?

\section{Discussion and Conclusion}

According to the results of the study, the teachers employed a number of strategies as part of problem-solving processes, as with the large number of studies that note the utilization of problems to facilitate the use of different strategies (Guven et al., 2016; Ishada, 2002; Özmen et al., 2012). The current study adds to the literature by identifying the strategies employed during the problem-solving processes in mathematics lessons.

In this regard, it was observed that the rate of application of strategies was rather low, even though specific strategies were nominally employed by the teachers. This situation supports the existing literature that refers to teachers' shortcomings in terms of developing different solution strategies for problems (Gürbüz \& Gider, 2016), as well as average levels of preference for problems requiring different strategies (Özmen et al., 2012). On the whole, this study found that the strategy most frequently employed by the teachers in problem solving was adopting a different point of view. In addition, the strategy of making a drawing was also frequently evidenced, as with Bruun (52013). The reason why teachers frequently prefer this strategy may be that middle school students learn more easily with concrete examples. Aside from this, the teachers were observed to employ the strategies of intelligent guessing and testing, working backwards, finding a pattern, solving a simpler analogous problem, and considering extreme cases, but with less frequency. However, the strategy of organizing data was not used by any of teachers, contrary to Abdurrahman et al. (2020), who demonstrated that participants with dominant kinesthetic intelligence developed a strategy of organizing data for solving problems. In this sense, the dominant intelligence of the teachers in present study may have prevented them from using the data organizing strategy.

In a study by Gürbüz and Gider (2016), teachers were asked to solve given problems, and the strategies they employed were identified. It was found overall that the teachers employed simplification of the problem as a strategy. When asked why they used this strategy, they noted that the problems presented to them were similar to the worker-pool problems frequently found in textbooks. The present study differs from Gürbüz and Gider (2016) in that we did not intervene with the teachers' choices regarding the selection of the problems. However, it was seen that the teachers used a similar simple problem-solving strategy. This indicates that this strategy is used both in solving problems similar to known problems and in solving more complex problems.

In the existing literature, studies indicate that most teachers report frequent use of problemsolving strategies (Ling \& Maat, 2020); however, while they indicate that they use numerous different strategies, none mention using all of the problem-solving strategies proposed by the National Mathematics Teachers Council (Bruun, 2013). In contrast, the findings of the present study indicate that the teachers used strategies on only a very limited basis. The reason for this result may be that previous studies relied on teachers' self-reporting, while the current study drew from direct classroom observations. 
It is recognized that offering alternative solutions to a problem is important for motivating students (Silver et al., 2005), improving attitudes towards problem solving (Altun \& Arslan, 2006) and fostering success (Yazgan \& Bintaş, 2005). Moreover, it has been emphasized that previous experience is a factor in the successful use of problem-solving strategies with similar problems (Charles \& Lester, 1982). As such, when teachers refrain from the use of certain strategies and make little or no mention of them, this leads to a lack of experience among students regarding the use of these strategies (Altun \& Arslan, 2006; Barham, 2020; Ramnarain, 2014; Yazgan \& Bintaş, 2005).

In this sense, Altun and Arslan (2006) found that seventh and eighth graders utilized the strategies of estimation and control, making a drawing, systematic listing, and problem simplification strategies to a certain degree, while they did not use the strategies of searching for relationships and working backwards at all. In contrast, the present study observed that teachers did utilize these strategies, albeit at limited rates. However, as no separate study was carried out with the students who were taught by the teachers who took part in the present study, the impact the teachers had on the students is relatively unknown. Future studies may elaborate on this issue.

Existing studies have so far revealed that certain strategies (e.g., making the problem simpler and modeling) are used frequently for the solution of certain types of problems (e.g., worker-pool and probability), leading to an increased use of these strategies (Gürbüz \& Gider, 2016). Yet while there are problem types that are better matches for a given strategy, these strategies nonetheless are not topic dependent.

In previous studies, the researchers chose the problems and asked the participants to solve them, with the subject context of the problems leading the participants to specific strategies. In contrast, in the present study, the use of strategies was observed by randomly selecting lessons. Furthermore, the observations were made at different grade levels, with no interventions in the teachers' choice of problems. This gave the researchers the opportunity to observe many problems and solution processes in different subjects. Even so, it was observed that the teachers used certain strategies more widely, as with Gürbüz and Gider (2016), who argued that teachers were focused on the results when solving the problems. In a similar vein, Altun and Arslan (2006) note that students are inclined to quickly reach the solution by applying the required operations with the numbers provided in the problems, as a result, perhaps, of the teachers' provision of model solutions for the problems discussed during the lessons, withholding from the students the opportunity to make authentic attempts.

Depaepe, Corte and Verschaffel (2010) and Özmen et al. (2012) argue that teachers are influenced by the obligation to make effective use of time in order to cover the whole curriculum. The teachers in the current study may have chosen the fastest method of reaching a solution for similar reasons. On the other hand, although there are time constraints and a need to address the entire curriculum, teachers have the ability to reduce the number of problems to be solved; additionally, lessons can be planned to focus on thinking about different solutions. In this context, it is thought that it would be beneficial for teachers to examine the curriculum in the context of problem-solving strategies and to receive training for strategy teaching. The aim in this sense may be to create in the mind of teachers that the curriculum is designed not only for the purpose of teaching concepts, but also for the use of strategies, which should be developed in order to gain problem-solving skills. In this regard, both in pre-service and in-service teacher education, solving a problem with multiple strategies should be discussed according to the learning objectives.

When the results of the study are evaluated in general, it can be said that the students experienced a limited number of strategies. This can be considered as a sign of focusing on results, rather than on the process of problem- solving. Thus, it can be suggested that teachers may improve students' thinking skills by focusing not only on the correct answer, but also on the solution processes of different strategies. In this sense, the critical role of learning activities in which students actively participate cannot be denied. Thus, it should be accepted that class discussions about different solution approaches may be more meaningful than solving large 
numbers of problems, as not all students can be expected to learn at the same level with a single method. In this regard, it should be considered that the solution of a problem using different strategies may provide the opportunity to address individual differences.

Finally, it should be noted that there were certain limitations to this study. Namely, the teachers were selected in terms of their level of experience in order to provide sample diversity. The data were not evaluated with a focus on the effect of experience on strategy use. As such, future studies may investigate the effects of experience on strategy use. In addition, class level and subject contexts were not considered as variables to illustrate the general situation. In future studies, the effect of these two variables on strategy use may be investigated.

Funding. This work was supported by Giresun University, Scientific Research Projects Coordination Unit, TURKEY [grand number EĞT-BAP-A-140316-113].

Acknowledgements. We are grateful to project researchers Mathematics Teacher Yağmur Çavuşoğulları and Mathematics Teacher Aslıhan Tepe for their contributions to the pre-study.

\section{References}

Abdurrahman, S. M., Abdullah, A. H., Shamsuddin, N. S., Rahman, S. N. S., Ashari, Z. M., Jumaat, N. F., Samah, N. A. \& Ali, D. F. (2020). Pupil's behaviour pattern and non-routine mathematical problemsolving strategy based on multiple intelligences. Journal of Advanced Research in Dynamical and Control Systems, 12(3), 446-485. http://doi.org/10.5373/JARDCS/V12I3/20201214

Achmetli, K., Schukajlow, S., \& Rakoczy, K. (2019). Multiple solutions for real-world problems, experience of competence and students' procedural and conceptual knowledge. International Journal of Science and Mathematics Education, 17(8), 1605-1625. https:// doi.org/10.1007/s10763-018-9936-5

Altun, M., \& Arslan, Ç. (2006). İlköğretim öğrencilerinin problem çözme stratejilerini öğrenmeleri üzerine bir çalışma [A study on learning of problem-solving strategies by secondary school students]. Uludă̆ Üniversitesi Eğitim Fakültesi Dergisi, 19(1), 1-21.

Altun, M., Memnun, D. S., \& Yazgan, Y. (2007). Sınıf öğretmeni adaylarının rutin olmayan matematiksel problemleri çözme becerileri ve bu konudaki düşünceleri [Primary school teacher trainees' skills and opinions on solving non-routine mathematical problems]. Ilköğretim Online, 6(1), 127-143.

Baki, A. (2015). Kuramdan uygulamaya matematik eğitimi [Mathematics Education from Theory into Practice]. Hece Yayınları.

Barham, A. I. (2020). Investigating the development of pre-service teachers' problem-solving strategies via problem-solving mathematics classes. European Journal of Educational Research, 9(1), 129-141. https://doi.org/10.12973/eu-jer.9.1.129

Bruun, F. (2013). Elementary teachers' perspectives of mathematics problem solving strategies. The Mathematics Educator, 23(1), 45-59.

Charles, R., \& Lester, F. (1982). Teaching problem solving: What, why and how. Dale Seymour.

Csíkos, C., \& Szitányi, J. (2020). Teachers' pedagogical content knowledge in teaching word problem solving strategies. ZDM, 52(1), 165-178. https://doi.org/10.1007/s11858-019-01115-y

Çepni, S. (2009). Araştırma ve proje çalışmalarnna giriş [Introduction to research and project work]. Celepler.

Depaepe, F., Corte, E., \& Verschaffel, L. (2010). Teachers' approaches towards word problem solving: Elaborating or restricting the problem context. Teaching and Teacher Education, 26(2), 152-160. https:/ / psycnet.apa.org/doi/10.1016/j.tate.2009.03.016

Follmer, R. (2000). Reading, mathematics and problem solving: the effects of direct instruction in the development of fourth grade students' strategic reading and problem solving approaches to textbased, nonroutine mathematics problems. Unpublished doctoral thesis, University of Widener, Chester, PA.

Foong, P. Y., \& Koay, P. L. (1997). School word problems and stereotyped thinking. Teaching and Learning, 18(1), 73-82.

Guven, B., Aydin-Guc, F. \& Özmen, Z. M. (2016). Problem types used in math lessons: The relationship between student achievement and teacher preferences. International Journal of Mathematical Education in Science and Technology, 47(6), 863-876. http://dx.doi.org/10.1080/0020739X.2015.1136438 
Gürbüz, R., \& Güder, Y. (2016). Matematik öğretmenlerinin problem çözmede kullandıkları stratejiler [The Strategies Mathematics Teachers Use in Problem Solving]. Journal of Kirsehir Education Faculty, 17(2), 371386.

Hembree, R. (1992). Experiments and relational studies in problem solving: a meta-analysis. Journal for Research in Mathematics Education, 23(3), 242-273. https://doi.org/10.2307/749120

Ho, F.K., \& Hedberg, G., J. (2005). Teachers' pedagogies and their impact on students' mathematical problem solving. Journal of Mathematical Behavior, 24(3-4), 238-252. https://doi.org/10.1016/ j.jmathb.2005.09.006

Ishida, J. (2002). Students' evaluation of their strategies when they find several solution methods. Journal of Mathematical Behavior, 21(1), 49-56. https:// doi.org/10.1016/S0732-3123(02)00102-5

Levav-Waynberg, A., \& Leikin, R. (2012). The role of multiple solution tasks in developing knowledge and creativity in geometry. Journal of Mathematical Behavior, 31, 73-90. https://doi.org/10.1016/ j.jmathb.2011.11.001

Ling, Y. S., \& Maat, S. M. (2020). Level of use of mathematical problem solving strategies among Kanowit district primary school teachers. International Journal of Novel Research in Education and Learning, 7(2), 4557.

Miles, M. B. \& Huberman, A. M. (1994). Qualitative data analysis: A sourcebook of new methods (2nd ed.). Beverly Hills, CA: Sage.

Ministry of National Education. (2017). Matematik öğretmeni özel alan yeterlikleri [Mathematics teacher special field competencies]. Devlet Kitapları Müdürlügüu.

Ministry of National Education. (2018). Matematik dersi öğretim programı (Illkokul ve ortaokul 1, 2, 3, 4, 5, 6, 7 ve 8. sinfflar)[Mathematics curriculum: 1-8. Grades]. Devlet Kitapları Müdürlüğü.

National Council of Teachers of Mathematics. (1989). Curriculum and evaluation standards for school mathematics. (1 ${ }^{\text {st }}$ ed.). National Council of Teachers of Mathematics.

National Council of Teachers of Mathematics. (2000). Principles and standards for school mathematics. National Council of Teachers of Mathematics.

Olkun, S., \& Toluk, Z. (2003). Matematik ögretimi [Mathematics teaching]. Anı Publ.

Özmen, Z. , Taşkın, D. \& Güven, B. (2012). İlköğretim 7. Sınıf matematik öğretmenlerinin kullandıkları problem türlerinin belirlenmesi [Determining the Types of Problems Used by 7th Grade Math Teachers]. Education and Science, (37)165, 246-261.

Posamentier, A. S., \& Krulik, S. (1998). Problem-solving strategies for efficient and elegant solutions. Corwin.

Ramnarain, U. (2014). Empowering educationally disadvantaged mathematics students through a strategiesbased problem solving approach. Australian Educational Researcher, 41(1), 43-57. https://doi.org/10.1007/s13384-013-0098-8

Rittle-Johnson, B., \& Star, J. R. (2007). Does comparing solution methods facilitate conceptual and procedural knowledge? An experimental study on learning to solve equations. Journal of Educational Psychology, 99(3), 561-574. https:/ / psycnet.apa.org/doi/10.1037/0022-0663.99.3.561

Rittle-Johnson, B., \& Star, J. R. (2009). Compared with what? The effects of different comparisons on conceptual knowledge and procedural flexibility for equation solving. Journal of Educational Psychology, 101(3), 529-544. https:// psycnet.apa.org/doi/10.1037/a0014224

Schukajlow, S., \& Krug, A. (2014). Do multiple solutions matter? Prompting multiple solutions, interest, competence, and autonomy. Journal for Research in Mathematics Education, 45(4), 497-533. https:// doi.org/10.5951/jresematheduc.45.4.0497

Silver, E. A., Ghousseini, H., Gosen, D., Charalambous, C., \& Strawhun, B. T. F. (2005). Moving from rhetoric to praxis: Issues faced by teachers in having students consider multiple solutions for problems in the mathematics classroom. Journal of Mathematical Behavior, 24(3-4), 287-301. https://psycnet.apa.org/doi/10.1016/j.jmathb.2005.09.009

Taspinar, Z., \& Bulut, M. (2012). Determining of problem solving strategies used by primary 8 , grade students' in mathematics class. Procedia-Social and Behavioral Sciences, 46, 3385-3389.

Wheatley, G. H. (1984). Problem solving makes math scores soar. Educational Leadership, 41(4), 52-53.

Yazgan, Y. \& Bintaş, J. (2005). İlköğretim dördüncü ve beşinci sınıf öğrencilerinin problem çözme stratejilerini kullanabilme düzeyleri [Fourth and fifth grade students' levels of using problem solving strategies: a teachıng experiment]. Hacettepe Üniversitesi Eğitim Fakültesi Dergisi, 28(28), 210-218.

Yıldırım, A., \& Şimşek, H. (2008). Sosyal bilimlerde nitel araştırma yöntemleri [Quantitative research methods in the social sciences]. Seçkin Yayınevi. 